\title{
Consumer contribution to food contamination in Brazil: modelling the food safety risk in the home
}

\author{
A contribuição do consumidor para a contaminação dos alimentos no Brasil: \\ modelagem do risco à segurança dos alimentos em residências
}

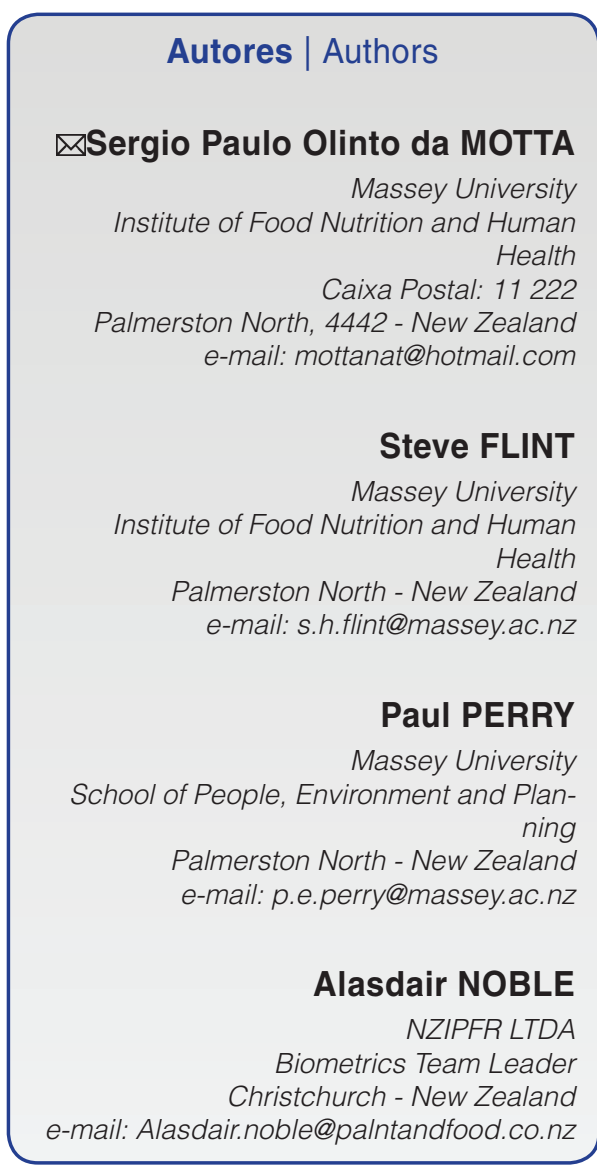

Autor Correspondente / Corresponding Author

Recebido / Received: 24/01/2014 Aprovado / Approved: 08/07/2014

Publicado / Published: jun./2014

\section{Summary}

Foodborne diseases are among the most widespread public health issues, killing about 2.2 million people annually, and costing hundreds of billions of US dollars for governments, companies, families and consumers (WHO, 2007). In Brazil, foodborne diseases acquired in the home account for $55 \%$ of notified outbreaks (BRASIL, 2012). Several studies have investigated aspects of consumer behaviour concerning food poisoning, mapping practices in the home, but it remains a challenge to obtain a full picture of the consumer contribution to food contamination (REDMOND and GRIFFITH, 2003). This study aimed to assess the risks of food contamination in the home. A questionnaire containing 140 questions concerning food safety knowledge, handling practices, personal hygiene and basic health care, covering the stages when the food is under the control of the consumer, was developed and used to gather data for analysis. Appropriate scores were attributed to the questions (consequences to food safety) and answers (likelihood of food contamination). A risk estimate algorithm and an appropriate risk ranking scale were used to assess the results. From August 2011 to March 2012, survey questionnaires were collected from 2,775 consumers in Brazil across 19 out of 27 state capitals. The study found risky practices with the potential to lead to food poisoning occurrences in the domestic environment in the following handling steps: food transportation, food preparation, cooking and the handling of leftovers. The personal hygiene, age, formal education, family income and basic health care habits represented the factors most related to the risky practices of consumers, which could orientate food safety educational campaigns for the Brazilian population.

Key words: Foodborne disease; Risk assessment; Food safety; Consumer behaviour. 


\section{Resumo}

As doenças transmitidas por alimentos (DTAs) estão entre os problemas de saúde pública mais comuns. As DTAs matam cerca de 2,2 milhões de pessoas anualmente e custam centenas de bilhões de dólares para os governos, as empresas, as famílias e os consumidores (WHO, 2007). No Brasil, a ocorrência de DTAs em residências representa 55\% dos surtos notificados (BRASIL, 2012). Diversos estudos têm investigado os aspectos do comportamento do consumidor ao manipular os alimentos, mapeando práticas em casa, mas permanece o desafio de se obter uma imagem mais precisa da contribuição do consumidor para a contaminação dos alimentos (REDMOND e GRIFFITH, 2003). Este estudo teve como objetivo estimar o risco de contaminação dos alimentos em residências. Um questionário contendo 140 perguntas sobre o conhecimento de boas práticas em segurança dos alimentos, práticas de manipulação, higiene pessoal e cuidados básicos de saúde, abrangendo as etapas enquanto os alimentos estão sob o controle do consumidor, foi desenvolvido e usado para reunir dados para análise. Pontuações apropriadas foram atribuídas às questões (consequências para a segurança dos alimentos) e às respostas (probabilidade de contaminação dos alimentos). Algoritmo para estimativa do risco e escala de classificação foram utilizados para avaliar os resultados. De agosto de 2011 a março de 2012, o questionário foi aplicado em 2.775 residências de 19 capitais, de todas as regiões do país. O estudo identificou práticas de risco com potencial para causar intoxicação alimentar no ambiente doméstico, nas seguintes etapas da manipulação: transporte de alimentos, preparação e cozimento de alimentos, e manuseio das sobras, com a higiene pessoal, a idade, a escolaridade, a renda familiar e os cuidados básicos de saúde, representando os fatores que estão mais relacionados com as práticas arriscadas dos consumidores, o que poderia orientar campanhas educativas sobre segurança dos alimentos para a população brasileira.

Palavras-chave: Doenças transmitidas por alimentos; Análise de risco; Segurança de alimentos; Comportamento do consumidor. 


\section{Introduction}

Food has always been present in the most important moments of human history; it is during a meal people usually do business, socialise with family and friends, and make decisions. As food trade expands worldwide, a meal can contain ingredients from various countries, cultivated, harvested, transported, processed and preserved with different technologies, as a consequence food safety has become a shared concern among both developed and developing countries (JUOKSLAHTI, 2003). Food can become contaminated at any stage, or in several stages from production to consumption with the potential to lead to food poisoning (CDC, 2011). Foodborne diseases are among the most widespread public health issues, killing about 2.2 million people annually, and costing hundreds of billions of US dollars for governments, companies, families and consumers (WHO, 2007).

Food producers, manufacturers and retailers carry the main responsibility for food safety and, as a result, have developed good strategies to ensure safe food. However, the consumer is the primary responsible for the consequences to their health if some preventive measures and safe food handling practices are not observed before consumption. When a person eats unsafe food and becomes ill, costs extend beyond consumers themselves to family members, healthcare workers, employers, the food supplier, and the government.

Food handling by the consumer is not controlled by regulations and therefore is of growing concern as a major risk factor in food safety (WHO, 2010). In Brazil foodborne diseases acquired in the home account for $55 \%$ of notified foodborne outbreaks (BRASIL, 2012). Previous studies have implicated food handlers and have shown improper food preparation practices in the domestic kitchen, contaminated equipment and food, to be a significant origin of food contamination, pathogens growth and possible survival (REDMOND and GRIFFITH, 2003). Indeed, research on foodborne outbreaks over the past few decades has focused on hospitals, restaurants, day-care facilities, and schools, but little attention has been paid to the home setting (AIELLO et al., 2008).

The safety of food at the moment of consumption is critical for human health and depends on many variables, what may include: criteria for checking the safety of food ingredients when choosing and purchasing food, food transportation, the storage and preservation of food, food preparation and cooking, the exposure of food to a dangerous temperature, the handling of leftovers, kitchen facilities and the use of kitchen appliances, and aspects of personal hygiene and the basic health care of food handlers. These are key factors likely to contribute to foodborne illness occurrences in the home.

\section{Food safety risk assessment}

Assessing risks is part of our daily life. When we cross the street, we decide whether or not it is safe to walk. This decision is based on what we have learnt about hazards on the street. Cars, buses, trucks, and cyclists are all hazards to the pedestrian, but some can hurt us more than others. Every time we start to cross a street, we estimate the likelihood that a vehicle will hit us and the extent of damage it could do.

Food safety risk assessment is a process that provides an estimate of the likelihood and impact of adverse health effects attributable to potentially contaminated foods, or simply, risk assessment is a measure of risk and the identification of factors that influence it. This approach includes hazard identification, hazard characterization, exposure assessment, and risk characterization (TUOMINEN, 2009).

There is a spectrum of approaches available for exposure assessment, ranging from qualitative to fully quantitative in nature. Qualitative exposure assessments are descriptive or categorical treatments of information, whereas quantitative assessments are mathematical analyses of numerical data. Semi-quantitative exposure assessment provides an intermediate level between the textual evaluation of qualitative exposure assessment and the numerical evaluation of quantitative exposure assessment by evaluating risks with a score (FAO, 2008). It offers a more consistent and rigorous approach to assessing and comparing risks and risk management strategies than qualitative exposure assessment, while avoiding some of the ambiguities that a qualitative exposure assessment may produce.

Semi-quantitative exposure assessment is a relatively new idea in food safety (FAO, 2008). When applying a semi-quantitative method for exposure assessment, it is helpful to use terminology that clearly distinguishes between likelihood assessment, consequence assessment and the risk estimate. According to this model, three major pillars for risk assessment can be described as follows (AUSTRALIAN GOVERNMENT, 2005):

Likelihood assessment

- Highly likely - is expected to occur in most circumstances.

- Likely - could occur in many circumstances.

- Unlikely - could occur in some circumstances.

- Highly unlikely - may occur only in very rare circumstances.

Consequence assessment

- Marginal - there is minimal or no negative impact.

- Minor - there is some negative impact. 
- Intermediate - the negative impact is substantial.

- Major - the negative impact is severe.

Risk estimate

- Negligible - risk is insubstantial and there is no present need for mitigation.

- Low - risk is minimal, but may invoke actions for mitigation beyond normal practices.

- Moderate - risk is of marked concern that will necessitate actions for mitigation that need to be demonstrated as effective.

- High - risk is unacceptable unless actions for mitigation are highly feasible and effective.

This study aimed to investigate consumer knowledge, practices and behaviour concerning food safety in Brazil, using the method of self-completed questionnaire, to provide information for modelling food safety risk assessment in the home.

\section{Material and methods}

Brazilians are not keen to respond to mailed questionnaires, with the response rate for this method usually lower than 15\% (NARESH, 2004). Therefore, the method chosen for data gathering in Brazil involved trained surveyors, delivering and collecting of questionnaires that were self-completed by people responsible for cooking in the home.

Between August 2011 and March 2012, 3,215 questionnaires were distributed to consumers from 19 out of the 27 state capitals nation-wide (covering all geographic regions), from which 2,775 were completed and assessed, a response rate of $86 \%$.

The data were normalised and analysed using $\mathrm{R}$ for Windows 3.0.1 and RStudio v 0.97.551 (downloaded for free from the internet - www.rstudio.com), using ANOVA for significance and Tukey HSD for comparison between variables investigated. Considering the sample size $(n=2,775)$ a value of 0.001 as a cut-off was applied ( $p<$ 0.001 ) for the ANOVA analysis, with significant differences at the .05 level.

\subsection{Data sample and demographics}

There were instructions recommending that the person usually responsible for cooking in the home should complete the questionnaire. In many countries, it is people within the range 20 - 59 years that are usually responsible for cooking for themselves and family. In Brazil, this age range represents $56 \%$ of the country's population (IBGE, 2011 ) and was represented by $84 \%$ of participants in the survey.

Brazil has a very balanced gender distribution within the population, $49 \%$ men and $51 \%$ women. In this study men were $22 \%$, with women being the majority of participants (78\%). This suggests that women are still primarily responsible for cooking in Brazilian households.

According to Instituto Brasileiro de Geografia e Estatística (IBGE, 2012), 50.2\% $(88,315,698)$ of the Brazil population of schooling age (10 years and over) had never been enrolled in a school or have some incomplete schooling, $7 \%$ of the Brazil population $(14,124,403)$ are below the schooling age ( 0 - 10 years), $17.4 \%$ $(30,733,862)$ are completed primary school and are enrolled in secondary school, $23.9 \%(42,214,904)$ are completed secondary school and are enrolled in tertiary education, and $7.9 \%(13,953,880)$ have already completed a tertiary or postgraduate education. Overall, 49\% of Brazil's population in schooling age have completed a formal qualification, while in this study was $83 \%$.

The most representative occupational status was the employed full-time with $43 \%$ of respondents, followed by people on home duties with $16 \%$. In the Brazil population, these groups are represented by $36 \%$ and $3 \%$, respectively.

According to IBGE (2011), Brazil has 100,223,000 in its economically active population, from which $24,190,000$ $(24 \%)$ are within the lower income category (lower than $\$$ $20,000 / y r)$. In this study, this was similar (27\%). In Brazil, higher income families (\$60,001 and over) represent 9\% of the economically active population; while in this study was $19 \%$.

Despite the high representation of participants in the survey of groups with a formal qualification, employed full-time and lower income classes, the sample was representative and the conclusions are still valid at least for those groups who were studied.

\subsection{Food safety risk assessment in the home}

Mapping the risks of food poisoning in the home is about assessing the food handling practices of consumers considering the occurrence of illness, its severity, associated pathogens and food-vehicles, through a model that can synthesize the contribution to food safety at various stages of food handling, when food is under the care of the consumer. Figure 1 presents a model for food safety risk assessment in the home, based on a questionnaire survey and a semi-quantitative risk assessment methodology.

A questionnaire following the usual process of cooking in the home was chosen for the data collection as a method more reliable than interviewing individuals (interviewer bias may apply) and able to be given to many people simultaneously, enabling coverage of a large number of people over a wide area (WOOD and KERR, 2006). In an attempt to simulate the usual process of 
FOOD SAFETY RISK ASSESSMENT IN THE HOME - MODELLING

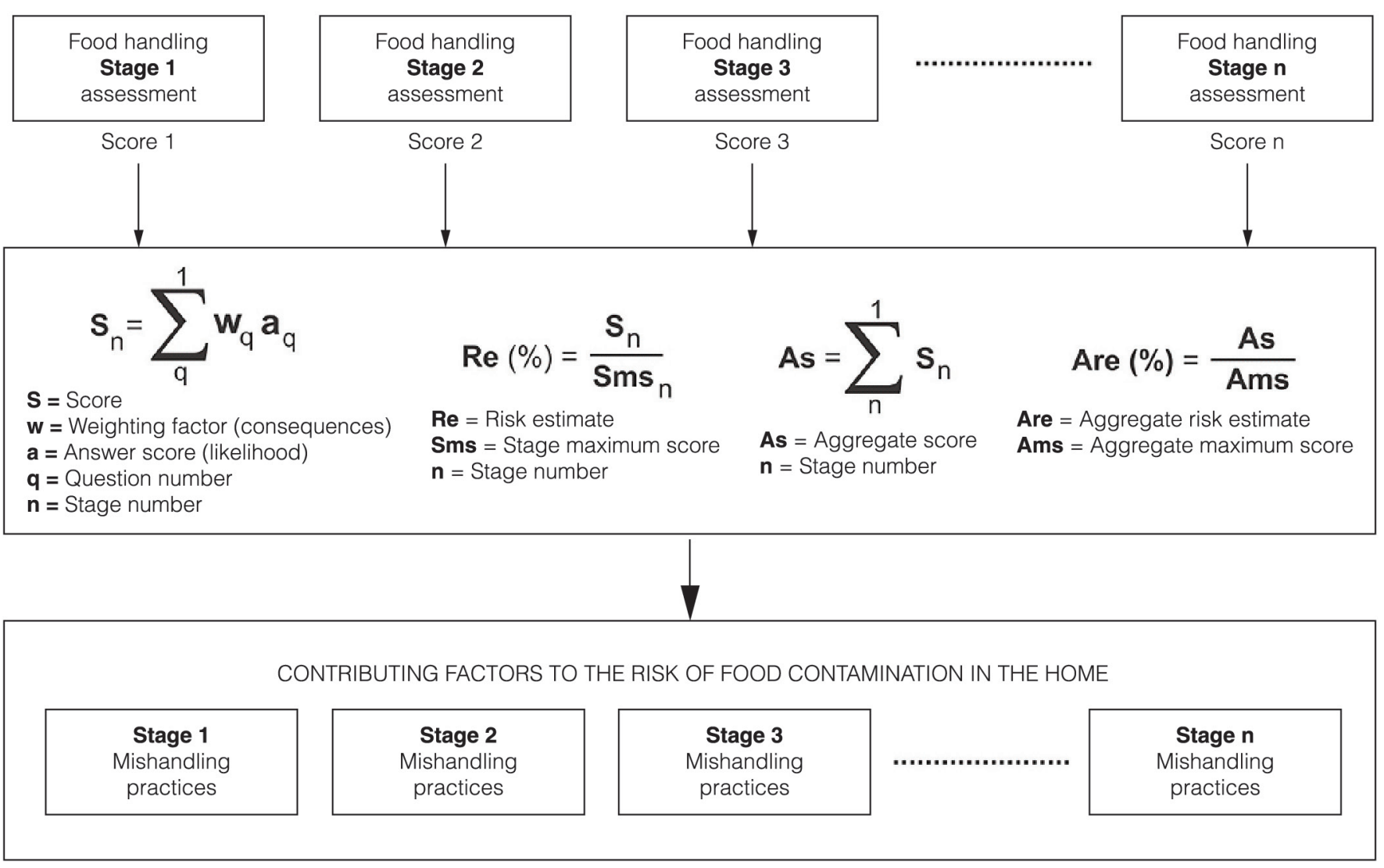

Figure 1. Modelling food safety risk assessment in the home - Framework.

cooking in the home, food safety practices investigated by this study were divided into eight sections:

- Stage 1 - Choosing and purchasing food;

- Stage 2 - Food safety knowledge;

- Stage 3 - Food transportation;

- Stage 4 - Storage and preservation of food;

- Stage 5 - Food preparation and cooking;

- Stage 6 - Handling of leftovers;

- Stage 7 - Kitchen facilities and the use of kitchen appliances;

- Stage 8 - Personal hygiene and basic health care.

The questionnaire used in this study had 140 questions. Each question with its specific weighting factor, varying from 0 (zero) to 9 (nine), representing the consequence to food safety, and each answer choice with a score, varying from 0 (zero) to 12 (twelve), representing the likelihood of food contamination from each specific practice (the chosen answer) (Table 1). The score of each question was obtained by multiplying the weighting factor by the answer score (chosen response).

\subsection{Risk estimate algorithm and data processing}

Individual descriptors can be incorporated into a Risk Estimate Matrix (AUSTRALIAN GOVERNMENT, 2005). Likelihood and consequences assessments are combined to give a risk estimate. Appropriate scores for consequences and likelihood can be applied to represent the risk of food contamination, pathogen growth or survival (Table 1).

The overall score (S) in each section of the questionnaire (stage of food handling) was obtained by the accumulation of points in the section, and corresponds to the contribution to the risk of food contamination at that stage (Figure 1). By dividing the overall score (S) obtained in each stage by the maximum score assigned for that stage (Sms), the risk estimate of food contamination in this stage of food handling was obtained. Then, the questionnaire aggregate score (As) was calculated by an accumulation of points in each section of the questionnaire and the aggregate risk estimate (Are) was obtained by dividing the aggregate score by the maximum score of the scale - 4,001 points (Table 2), representing the highest likelihood of food contamination and major consequences.

An appropriate risk scale divided into four levels (Negligible $<10 \%, 10 \% \leq$ Low $<33 \%$, 
Consumer contribution to food contamination in Brazil: modeling the food safety risk in the home

MOTTA, S. P. O. et al.

Table 1. Risk Estimate Matrix ${ }^{(1)}$ (Adapted from Australian Government, 2005).

\begin{tabular}{cllccccc}
\hline $\begin{array}{c}\text { LIKELIHOOD OF FOOD } \\
\text { CONTAMINATION, }\end{array}$ & Highly Likely (12) & Low & Moderate & High & High \\
PATHOGEN GROWTH OR & Likely (6) & Negligible & Low & High & High \\
SURVIVAL & Unlikely (3) & Negligible & Low & Moderate & High \\
(Answer score) & Highly Unlikely (0) & Negligible & Negligible & Low & Moderate \\
& & Marginal (0) & Minor (3) & Intermediate (6) & Major (9) \\
& & \multicolumn{2}{c}{ CONSEQUENCES TO FOOD SAFETY (Question weighting) } \\
\hline
\end{tabular}

${ }^{(1)}$ Scores attributes can be found between brackets.

Table 2. Questionnaire design and risk mitigation (control).

\begin{tabular}{|c|c|c|c|c|c|}
\hline \multicolumn{6}{|c|}{ QUESTIONNAIRE DESIGN } \\
\hline \multicolumn{2}{|r|}{ Questionnaire Section (stage of food handling) } & $\begin{array}{c}\text { Qty of } \\
\text { Questions }\end{array}$ & $\begin{array}{c}\text { Maximum Score } \\
\text { / Stage (Sms) }\end{array}$ & $\begin{array}{c}\% \text { of Aggregate } \\
\text { Score }\end{array}$ & $\begin{array}{l}\text { Risk Mitigation } \\
\text { (Control) }\end{array}$ \\
\hline 1 & Choosing and purchasing food & 5 & 225 & $5.6 \%$ & 75 \\
\hline 2 & Food safety knowledge & 53 & 1,513 & $37.8 \%$ & 504 \\
\hline 3 & Food transportation & 2 & 108 & $2.7 \%$ & 36 \\
\hline 4 & Storage and preservation of food & 21 & 630 & $15.7 \%$ & 210 \\
\hline 5 & Food preparation and cooking & 18 & 756 & $18.9 \%$ & 252 \\
\hline 6 & Handling of leftovers & 4 & 243 & $6.1 \%$ & 81 \\
\hline 7 & Kitchen facilities and the use of kitchen appliances & 18 & 213 & $5.3 \%$ & 71 \\
\hline 8 & Personal hygiene and basic health care & 10 & 313 & $7.8 \%$ & 104 \\
\hline & Demographic data & 9 & 0 & $0.0 \%$ & 0 \\
\hline & AGGREGATE & 140 & 4,001 & $100.0 \%$ & \\
\hline
\end{tabular}

$33 \% \leq$ Moderate $<50 \%$ and High $\geq 50 \%$ ) was used for ranking the aggregate risk estimate (Are) (Figure 2). A risk estimate of $100 \%$ means that a person is likely to contaminate food every food handling and $0 \%$ means that is highly unlikely. Then, a risk mitigation (control) placed at the lower limit of the moderate risk ranking (33\% in the risk ranking scale), was used as a trigger to suggest the need for control measures.

A database (www.foodsafety.net.br) was developed for gathering all questionnaire responses, the computation of the scores, risk estimate calculations and the export of the data in Excel format. From the report covering the prevalence of food handling practices (frequency of responses), contributing factors leading to food contamination in the home were readily identified.

\section{Results}

\subsection{Risk estimate across stages of food handling}

The risk estimates for each stage of food handling were calculated and plotted against the risk mitigation (control) to identify the critical control points for food safety in the home in Brazil (Figure 3).

Overall survey findings indicated that consumers in Brazil are exposing food to a risk of contamination and this is through mishandling practices during food

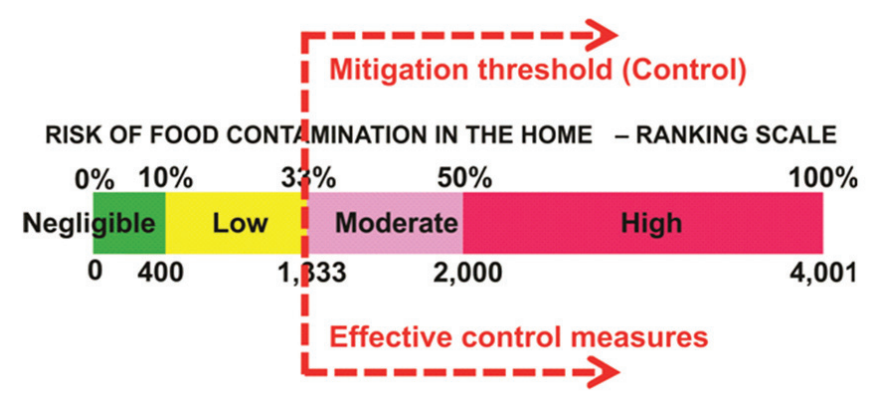

Figure 2. Risk ranking scale.

transportation ( $S=42 ; \operatorname{Re}=38.9 \%$ ), food preparation and cooking ( $S=289 ; \operatorname{Re}=38.3 \%$ ) and when handling leftovers ( $S=112 ; \operatorname{Re}=45.9 \%$ ), pivotal stages for food safety before consumption (Table 3 ).

Although there were food safety issues concerning kitchen facilities and the use of kitchen appliances ( $R e>$ $33 \%$ ), these weren't significantly above the risk mitigation (control).

\section{Discussion}

\subsection{Choosing and purchasing food (CPF)}

The age was the only significant variable influencing the consumer behaviour during choosing and purchasing food. Even observing a risk reduction with ageing in the 
Consumer contribution to food contamination in Brazil: modeling the food safety risk in the home MOTTA, S. P. O. et al.

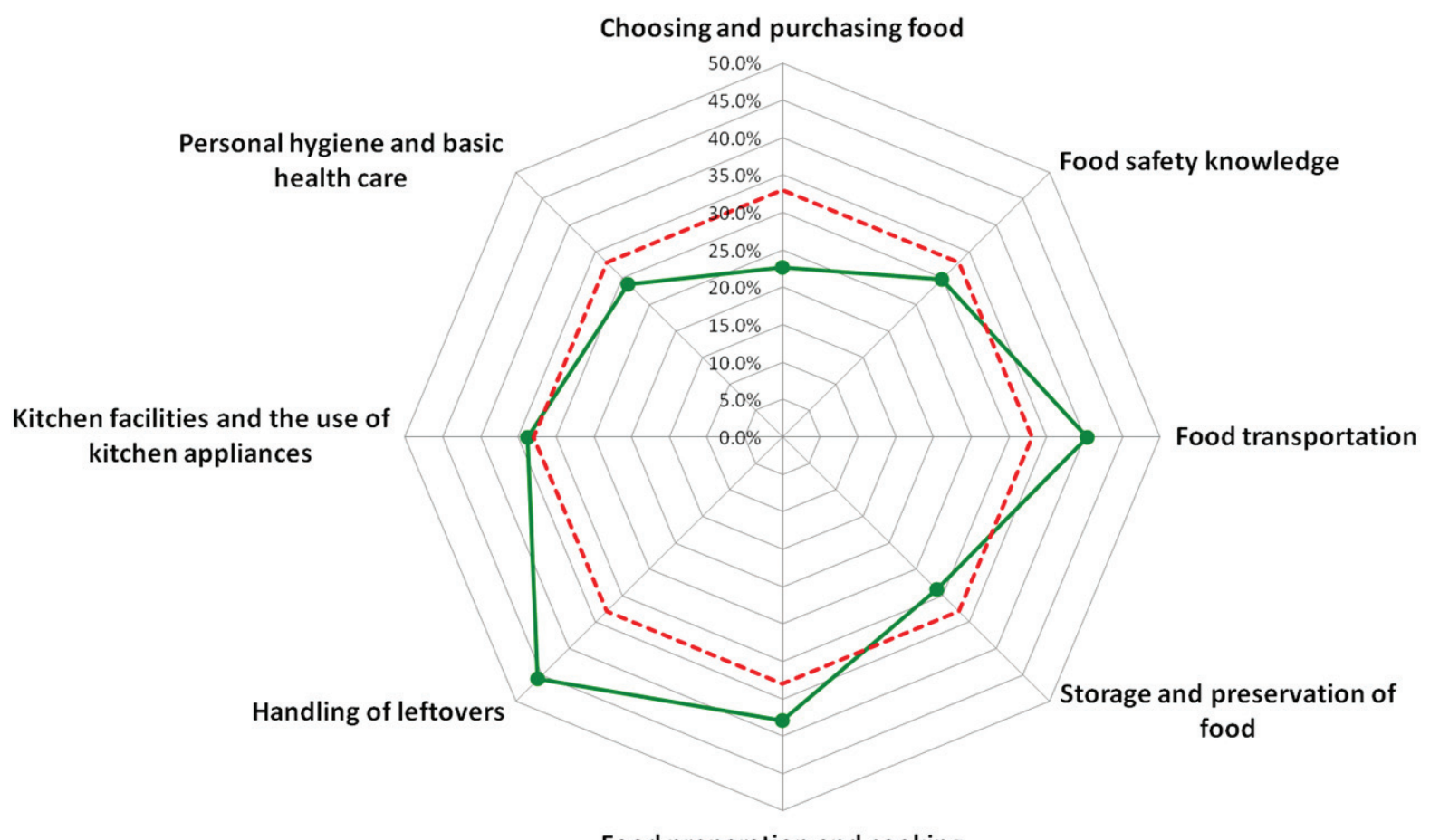

Food preparation and cooking

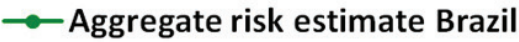

----Risk mitigation (control)

Figure 3. Risk estimate across various stages of food handling in the home in Brazil.

Table 3. Risk of food contamination in the home in Brazil.

\begin{tabular}{|c|c|c|c|c|}
\hline \multicolumn{5}{|c|}{ THE CONSUMER CONTRIBUTION TO FOOD CONTAMINATION } \\
\hline \multirow[t]{2}{*}{ Contributing factors (Stages of food handling) } & \multicolumn{2}{|c|}{$\begin{array}{c}\text { Brazil } \\
(n=2,775 ; p<0.0001)\end{array}$} & \multicolumn{2}{|c|}{$\begin{array}{l}\text { Risk Mitigation } \\
\text { (Control) }\end{array}$} \\
\hline & (S) & $(\mathbf{R e})$ & (S) & $(\mathbf{R e})$ \\
\hline Choosing and purchasing food & 51 & $22.8 \%$ & 75 & $33.3 \%$ \\
\hline Food safety knowledge & 451 & $29.8 \%$ & 504 & $33.3 \%$ \\
\hline Food transportation & 42 & $38.9 \%$ & 36 & $33.3 \%$ \\
\hline Storage and preservation of food & 184 & $29.2 \%$ & 210 & $33.3 \%$ \\
\hline Food preparation and cooking & 290 & $38.3 \%$ & 252 & $33.3 \%$ \\
\hline Handling of leftovers & 112 & $45.9 \%$ & 81 & $33.3 \%$ \\
\hline Kitchen facilities and the use of kitchen appliances & 73 & $34.1 \%$ & 71 & $33.3 \%$ \\
\hline Personal hygiene and basic health care & 91 & $29.1 \%$ & 104 & $33.3 \%$ \\
\hline
\end{tabular}

$(\mathrm{S})=$ Score; $(\mathrm{Re})=$ Risk estimate .

interval $20-59$ years $(F(5,2732)=17.63 ; p<0.0001)$ and a significant difference between the younger categories (under 20 years; $S=59$; $R e=26.3 \%$ ) and the mature (50-59 years; $S=42 ; \operatorname{Re}=18.6 \%)(p<0.0001)$, all categories had a risk estimate below the control $(\mathrm{Re}=33 \%)$.

For more than $80 \%$ of consumers in Brazil, the cleanliness and comfort of food premises are key drivers when choosing a place to buy food. About $60 \%$ grab chilled and frozen food at the end of their purchasing visit, $80 \%$ declared they always check for damaged packages, $88 \%$ check for "best before" and "use by" dates on labels and more than 55\% always verify the integrity of frozen packages. All of those are good practices concerning food safety when choosing and purchasing food.

\subsection{Food safety knowledge (FSK)}

The survey findings indicated that the consumer in Brazil has a lack of food safety knowledge and this was associated with their formal education $(F(4,2715)=60.91$; $p<0.0001)$, family income $(F(5,2635)=29.95 ; p<0.0001)$ and the awareness of their responsibility for food safety $(F(6,2730)=93.9 ; p<0.0001)$. 
People who have no formal schooling had the highest risk related to FSK ( $S=514$; $R e=34.0 \%$ ) above the risk mitigation (control) while people who achieved higher qualifications had a lower risk ( $S=369$; $\operatorname{Re}=24.4 \%$ ).

There was a trend for reduced risk with increased education and a significant difference between those without formal schooling and postgraduate education $(p<0.0001)$. Thus, there are factors associated with formal education affecting the safe food handling, such as: contents related to food safety principles are not covered at the primary level of formal education in public and private schools in Brazil, which is a necessary basis to acquire food safety principals. Furthermore, on the vocational and tertiary levels, there is no continuation of food safety contents if an individual is not enrolled in programmes oriented towards food handling. Improving the education in Brazil is a long-term challenge.

The risk estimate based on formal education was linked to the following contributing factors: only $9.7 \%$ of participants were aware of the consumer's responsibility concerning food safety and only $7 \%$ considered the home a place where food is likely to become contaminated, with $42 \%$ thinking of food safety when handling food at home. The great majority $(83 \%)$ regarded bacteria, pesticide residues (74\%) and adulterated foods (77\%) as the only potential hazards to food safety (low concerns about physical particles, allergens and GM foods) and 65\% of respondents did not recognize meat and eggs as a vehicle for microbes. Salmonella was the only pathogen of major concern for $35 \%$ of them. Overall, this lack of food safety knowledge could be correlated with formal education.

Family income was associated with consumer knowledge concerning food safety in Brazil with increasing income related to reduced risk. This is similar to the trend observed for formal education and the two may be linked. There was a significant difference between the food safety knowledge of the food handlers in low income households (lower than $\$ 20,000 / y r: S=494 ; R e=32.6 \%$ ) and families earning high incomes $(\$ 80,001 / \mathrm{yr}-\$ 100,000 / \mathrm{yr}: \mathrm{S}=376$; $R e=24.9 \%)(p<0.0001)$. The pattern observed where the risk estimate reduces with increasing income makes sense, because an increase in disposable income may reduce the tendency to use leftovers and will encourage the purchase of better quality food (usually more expensive) and to upgrade kitchen facilities.

The awareness of food safety as a shared responsibility plays an important role in consumer behaviour concerning food safety in Brazil. People who are aware that food can become contaminated at any stage from production to consumption ( $\mathrm{S}=384$; $\mathrm{Re}=25.4 \%$ ) and knowledgeable about their contribution to food safety when handling food in the home $(S=439$; $R e=29.0 \%$ ) had a significantly lower risk than those groups who think food safety is an individual responsibility (i.e.: farmers' responsibility: $S=565 ; \operatorname{Re}=37.4 \%)(p<0.0001)$. Usually, people who have a broader vision of risks associated with something tend to behave much cautious. Teaching consumers that food safety is a group responsibility should be an important part of food safety education.

Overall, a reduced risk of food contamination was associated with increasing income and formal education, suggesting a correlation that could target a nation-wide educational campaign concerning food safety in Brazil, which currently does not exist.

\subsection{Food transportation (FT)}

The food transportation stage is the second highest concern in human behaviour for Brazil (Figure 3), with many variables associated with the risky behaviour of consumers: age $(F(5,2732)=8.76 ; p<0.0001)$, formal education $(F(4,2715)=29.36 ; p<0.0001)$, occupational status $(F(7,2705)=16.05 ; p<0.0001)$, income $(F(5,2635)=29.03 ; p<0.0001)$ and region of living $(F(4,2748)=23.8 ; p<0.0001)$.

Survey findings suggest that all age categories have been mishandling food during transportation with risk scores above the risk mitigation (control), suggesting the need for a risk communication campaign focusing on safe methods for food transportation, with special attention to the young (under 20 years) at a higher risk. Furthermore, a significant difference was observed between practices of the young (under 20 years: $S=52 ; \operatorname{Re}=48.4 \%$ ) and mature people $(50-59$ years: $S=40 ; \operatorname{Re}=36.8 \%)$ $(p<0.0001)$.

The method used to transport food is a key factor to keep food safety, and this may be linked with formal education. There was a trend in risk reduction with improved schooling $(p<0.0001)$. However, all categories had a risk score above the risk mitigation (control). Those who had no formal schooling or, only attended primary school had the highest risk score related to FT ( $S=51$; $R e=47.4 \%$ and $S=47 ; R e=43.5 \%$, respectively), while people who achieved a higher qualification (postgraduate) had a lower risk score ( $\mathrm{S}=34 ; \mathrm{Re}=31.6 \%$ ).

Although all categories of occupational status had a risk score above the risk mitigation (control), those on home duties represented the group with the highest risk ( $S=51 ; R e=47.5 \%)$ most concern, while those employed full-time ( $\mathrm{S}=39 ; \mathrm{Re}=36.0 \%$ ) were of less concern. This suggests that people employed full-time take extra care with food transportation compared to those on home duties. Interestingly, more than other groups, people on home duties should be expected to follow good practices concerning food safety, because they are responsible for the preparation of family meals, but this was not supported by the survey data. Maybe when those responsible for 
home duties go shopping for food, they are likely to spend time on other personal activities before returning home. In Brazil, women are still likely to be responsible for shopping for food and cooking at home, and many supermarkets have been localised in shopping malls with many distractions.

The total income of everyone in a household was associated with food transportation practices of consumers, with high income reducing the risk $(p<0.0001)$. This is similar to the trend observed for formal education and may be linked. The pattern observed where the risk reduces with increasing income makes sense, because an increase in disposable income may encourage the purchase of better quality food and, such people may be more likely to have a car and that facilitates to getting home fast after shopping for food. The low income categories ( $<\$ 60,000 / y r)$ had risk scores above the risk mitigation (control), with the lowest income families (lower than \$20,000/yr) had the highest risk score ( $S=51$; $\mathrm{Re}=46.9 \%)$ and showed the largest variation concerning food transportation practices, while high income families $(\$ 80,001 / y r-\$ 100,000 / y r)$ had the lowest risk score ( $\mathrm{S}=34 ; \operatorname{Re}=31.1 \%$ ).

Among consumers that participated in the survey, more than $74 \%$ of respondents, mainly those in the low income category reported spending less than 30 minutes returning home after shopping for food. However, the majority declared they go shopping for food by bicycle, bus or walking. These are methods that may take some time and are more likely to expose food to dangerous temperatures. The risk may be exacerbated in large cities with the practice of purchasing food in big supermarkets distant from home.

People behave differently with regard to food transportation across different regions of Brazil, with the majority exposing food to the risk of contamination. As Brazil is a continental country with a large miscegenetic society, huge cities and long travel distances from home to the shops, this stage of food handling represented a great risk of food contamination. The North and Northeast regions share a similar level of food mishandling ( $S=46$; $R e=42.9 \%$ and $S=47 ; R e=43.2 \%$, respectively), while other regions behave quite differently. The highest risk score came from the southeast region $(S=49$; $\mathrm{Re}=45.4 \%$ ), the most heavily populated region, with the largest cities, and long distances to transport food home. In larger cities in Brazil, supermarkets are usually localized in shopping malls, distant from housing suburbs.

The Midwest ( $\mathrm{S}=38$; $\mathrm{Re}=34.8 \%$ ) and South $(\mathrm{S}=39 ; \mathrm{Re}=35.6 \%)$ regions shared similar risk scores, lower than other regions. Interestingly, the Midwest with the lower risk score had the highest average formal education level, where $72 \%$ had achieved a university or postgraduate level qualification. Furthermore, mature people, those who have achieved a higher education and are employed full-time, and families with high income had the lowest risk scores. Such people may be more likely to have a car and live closer to a high quality food supplier and that facilitates getting home fast after shopping for food.

\subsection{The storage and preservation of food (SPF)}

As a critical factor to ensure safe food at the moment of consumption, the storage and preservation of food does not seem to expose food to a risk of contamination in the home in Brazil $(F(3,2739)=29.83$; $p<0.0001)$. However, significant differences in risk scores were found associated with the basic health care habits of consumers, mainly between those who take oral rehydration first and later visited a GP/Health clinic ( $\mathrm{S}=177 ; \mathrm{Re}=28.1 \%$ ) and who do nothing when affected by gastroenteritis ( $\mathrm{S}=221$; $\mathrm{Re}=35.2 \%)(\mathrm{p}<0.0001)$.

Among risky practices related to the storage and preservation of food, $27 \%$ of participants indicated that they thaw frozen food on the bench top - at room temperature and $15 \%$ without concern, using any method of defrosting. Approximately $64 \%$ believe that cooked food should be cooled to room temperature before storage in the fridge, $30 \%$ of respondents never adjust the fridge dial-setting and $41 \%$ do not know what the appropriate conservation temperature is.

\subsection{Food preparation and cooking (FPC)}

Food preparation and cooking is an important stage for food safety before consumption, where the contamination of food can be reduced or increased. This was the third stage of most concern in the home in Brazil (Figure 3) and significantly associated with the risk taking behaviour of consumer as a consequence of the way they learned to $\operatorname{cook}(F(4,2722)=21.61 ; p<0.0001)$.

People who learned to cook at a training course had a low risk ( $S=236$; $\mathrm{Re}=31.2 \%$ ) below the risk mitigation (control), while those who learned to cook by themselves ( $\mathrm{S}=298$; $\mathrm{Re}=39.4 \%$ ), from cookery books or TV programmes ( $S=309$; $R e=40.9 \%$ ), partners $/$ friends ( $S=296$; $R e=39.2 \%$ ) or other relatives ( $S=275$; $\mathrm{Re}=36.4 \%)$ were at a high risk. These findings suggest the need for improving education concerning safe cooking, in special for those on home duties.

Overall, these were the practices reported by consumers in Brazil that contributed most to the risk of food contamination during food preparation and cooking in the home:

- More than $69 \%$ are likely to cook at home everyday / almost everyday, with 53\% cooking all meals and $17 \%$ breakfast only - Usually, as 
higher the frequency of food handling, the higher the risk of contamination;

- Almost $60 \%$ of the participants learned to cook from relatives (parents, grandparents), which tend to teach their own unsafe legacy practices (myths and beliefs);

- For about $62 \%$, the method used for checking if chicken and meat are thoroughly cooked is when it tastes cooked or just checking the texture (risky practice);

- About $47 \%$ consider ethnicity and food culture (including friends and family) as the most important factor associated with their cooking methods and recipes. For $31 \%$ there is no external factor (self-confidence);

- The great majority of participants (65\%) usually wash their hands after handling raw chicken or meat, but only $18 \%$ do it properly (because of inadequate washing time and unsafe methods used for drying their hands).

\subsection{Handling of leftovers (HL)}

A modern practice in large cities, resulting from long working journeys and large distances to get from the place of work to home, see people eating out and bringing back home leftovers for later consumption. This exposes food to the risk of contamination and represented the stage of most concern in Brazil (Figure 3). This was significantly associated with the food safety behaviour of consumers $(F(4,2717)=10.68 ; p<0.0001)$.

Despite all groups having risk scores above the risk mitigation (control), consumers that attended cooking classes at school were exposed to lower risk ( $S=92$; $\mathrm{Re}=37.8 \%)$ than others that followed legacy practices (ethnicity and food culture) ( $S=115 ; \operatorname{Re}=47.3 \%$ ), cookbooks ( $S=103 ; \operatorname{Re}=42.5 \%)$, TV Programmes and the internet ( $S=107 ; R e=44.2 \%$ ) or followed their own beliefs $(S=110 ; R e=45.3 \%)$, resulting in a significant difference in behaviour between categories.

Overall, these were the practices of consumers contributing most to the risk of food contamination when handling leftovers:

- About $38 \%$ of participants leave leftovers on the stove or bench top, until they are eaten or until the food is cool before transferring to the fridge;

- More than $61 \%$ declared re-heat leftovers until they get really hot (subjective criteria), but only $4 \%$ have a thermometer for checking the temperature.

\subsection{Kitchen facilities and the use of kitchen appliances (KFA)}

The way a person uses kitchen facilities and appliances can expose food to contamination. In Brazil, the kitchen layout was significantly associated with the risky behaviour of consumers $(F(1,2570)=65.72 ; p$ $<0.0001)$. People using a straight line kitchen design represented $54 \%$ of households in the survey and these had a higher risk $(S=84 ; R e=39.4 \%$ ), suggesting the need for control measures. There was a significant difference in food safety practices of that group compared with those using a triangle design ( $\mathrm{S}=57 ; \mathrm{Re}=26.9 \%$ ), represented by $39 \%$ of respondents.

Food mishandling linked to those using appliances in a straight line kitchen, that were associated with risky practices of consumers in Brazil were:

- More than $40 \%$ keep using a single wooden cutting board for handling raw and cooked food (risk of cross-contamination);

- Only $4 \%$ of households had a food thermometer and $34 \%$ a fridge thermometer. However, about $80 \%$ do not know their fridge temperature or are inappropriately setting the fridge dial;

- Only half of the respondents are likely to fully read the operating instructions of kitchen appliances (i. e.: microwave oven and fridge).

\subsection{Personal hygiene (PH)}

Personal hygiene $(\mathrm{PH})$ was the most important contributing factor linked with the risk of food contamination in the home in Brazil, with age $(F(5,2732)=65.72$; $p<0.0001)$, at-risk persons living in the home $(F(3,2708)=125.4 ; p<0.0001)$, and occupational status $(F(7,2705)=10.9 ; p<0.0001)$ associated with hygiene habits of consumers.

The elderly (60 or older) had a high risk score $(S=139 ; R e=44.6 \%)$, indicating the need for education to improve their personal hygiene practices. There was a trend for a reduced risk with ageing, from the young (under 20 years: $S=96 ; R e=30.6 \%)$ until the mature $(50-59$ years: $S=78 ; R e=24.8 \%$ ). Mature people tend to have achieved a higher education and overall knowledge, and as a consequence are earning higher salaries than the young or elderly, usually retired.

Brazilian households with an at-risk person (children under 5, elderly above 60, pregnant or an immuneimpaired) were under significant risk of food contamination $(S=113 ; R e=36.0 \%)$, resulting from the poor hygiene practices of the food handler. Households without an at-risk person had lower risk ( $S=80 ; \operatorname{Re}=25.4 \%$ ). Generally, residences with children under 5 are usually 
inhabited by young couples, what could indicate the need for target educational campaigns.

The occupational status of the consumer was associated with their personal hygiene practices. Except for the retired, all categories had risk estimates below the risk mitigation (control). The retired (usually elderly) had the highest risk estimate ( $S=116$; $R e=37.2 \%)$. This was very similar to the age results where the elderly are under high risk.

As a critical factor for aggravating health conditions, the basic health care habits of consumers in Brazil were associated with their risky practices concerning food safety $(F(3,2739)=783.7 ; p<0.0001)$.

Once again, people that self-medicate $(S=119$; $\mathrm{Re}=38.1 \%)$ or usually do nothing ( $\mathrm{S}=176$; $\mathrm{Re}=56.2 \%)$, when affected by gastroenteritis, had risk scores indicative of a need for improvements in their basic health care habits. A highly significant difference was observed between those who visited a GP or health clinic ( $S=66$; $\mathrm{Re}=21.1 \%$ ) when suffering from gastroenteritis (the appropriate attitude) and those who treated foodborne illness is a minor disease and do nothing (risky behaviour) $(p<0.0001)$.

Overall these were the practices contributing to the risk of food contamination associated with the personal hygiene and basic health care habits of the consumers in Brazil:

- The largest category of respondents (30\%) indicated a lack of food-safety knowledge and good personal hygiene practices as the factor influencing the non-adoption of good practices in food safety;

- About 29\% of participants were in the "at-risk" group for acquiring foodborne illness (children under 5, people above 60, pregnant or immuneimpaired);

- About 68\% declared there was no external agent associated with their personal hygiene habits such as: partner, school, church, leisure centre, educational campaigns, TV, newspaper, radio, media in general (self-confident behaviour);

- The percentage of participants in the survey who had experienced gastroenteritis with various symptoms indicative of foodborne illness over the past six months were: stomach ache with diarrhoea ( $25 \%$ of cases), lack of energydehydration (22\%) and chills/muscle aches (17\% of cases);

- About $53 \%$ of participants self-medicate as first care for what is probably self diagnosed gastroenteritis, and this may contribute to the underreporting of cases or aggravate existing health conditions.

\section{Conclusion}

The present study was a completely new investigation examining the risk of food contamination, pathogen growth or survival at various stages of food handling when food is under the control of the consumer. It supported and extended earlier studies and applied a new model for food safety risk assessment in the home. The risks of food contamination in Brazilian households were linked to unsafe practices, especially related to food transportation, food preparation and cooking and the handling of leftovers (Figure 3). Because the handling of leftovers contributed most to the aggregate risk estimate, but not significantly in terms of differences between categories, this suggests the need for further research extending the investigation into the detailed practices of this stage of food handling in the home in Brazil.

Variables that were associated most with high scores for the risky practices of consumers were age group, formal education, income of everyone in the household, ethnicity/race, region of living, basic health care, awareness of responsibility for food safety and the way the consumer learns to cook.

Based on these behavioural tendencies, it is recommended a more rigorous observation of food law requirements by manufacturers and commercial enterprises and the strengthening of the Brazil sanitary surveillance system, as well as the development of an intervention programme by government authorities, with the following targeted food safety campaigns, in order to address mishandling practices found in Brazil households:

- What are the major risks to food safety in the home;

- Information on safe purchasing and transportation of chilled or frozen foods;

- What to look for and how to check the safety of ready-to-eat and canned foods;

- Information concerning food preservation;

- The importance of personal hygiene and basic health care for food safety;

- Appropriate hand washing and drying before handling food and eating, and after using the toilet;

- Information concerning the prevalence of pathogens, food vehicles and severity of foodborne diseases across country regions;

- Myths and beliefs concerning food safety;

- The importance of time and temperature for pathogen growth;

- The appropriate use of the microwave oven and fridge; 
Consumer contribution to food contamination in Brazil: modeling the food safety risk in the home MOTTA, S. P. O. et al.

- Safe methods to check if meat is thoroughly cooked.

Although efforts to implement a food safety culture within a population do not necessarily lead to good foodsafety practices, the results indicated that educational campaigns, especially for households with at-risk persons living in the home (elderly, children under 5, the pregnant and immune-impaired), in low income families and in groups with low formal education, can be potentially useful in promoting safer food handling practices and reducing the occurrence of foodborne diseases in Brazil households.

\section{Acknowledgments}

The authors thank to the Institute of Food Nutrition and Human Health at Massey University - Palmerston North - New Zealand.

\section{References}

AIELLO, A. E.; LARSON, E. L.; SEDLAK, R. Personal Health: Bringing Good Hygiene Home. American Journal of Infection Control, St. Louis, v. 36, n. 10, p. S151-S165, 2008. Supplement.

AUSTRALIAN GOVERNMENT. Risk Assessment. In: AUSTRALIAN GOVERNMENT. Risk Analysis Framework. Australia: Office of the Gene Technology Regulator, 2005. cap. 3, p. 35-48. Disponível em: <http://www.ogtr.gov.au/internet/ogtr/publishing. nsf/content/raf-3/\$FILE/raffinal2.2.pdf>.

BRASIL. Ministério da Saúde. Secretaria de Vigilância em Saúde. Sistema Nacional de Vigilância em Saúde: Relatório de Situação. Brasilia, 2012.

CENTERS FOR DISEASE CONTROL AND PREVENTION - CDC. The Food Production Chain: How Food Gets Contaminated. Atlanta. Disponível em: <http://www.cdc.gov/foodsafety/ outbreaks/investigating-outbreaks/production-chain.html>. Acesso em: 1 jun. 2011.

FOOD AND AGRICULTURE ORGANIZATION - FAO. Exposure Assessment of Microbiological Hazards in Food: Guidelines.
Rome, 2008. 102 p. (Microbiological Risk Assessment Series, 7). Disponível em: <http://www.who.int/foodsafety/publications/ micro/MRA7.pdf>. Acesso em: 1 jun. 2011.

INSTITUTO BRASILEIRO DE GEOGRAFIA E ESTATÍSTICA - IBGE. Censo Demográfico 2010: Resultados Gerais da Amostra. Rio de Janeiro, 2012. Disponível em: <http://www.ibge.gov.br/home/ presidencia/noticias/imprensa/ppts/0000000847310412201231 5727483985.pdf>.

INSTITUTO BRASILEIRO DE GEOGRAFIA E ESTATISTICA - IBGE. Pesquisa Nacional por Amostras de Domicílios: PNAD 2011. Rio de Janeiro, 2011. v. 31, 135 p.

JUOKSLAHTI, T. Food Safety Issues in Food Trade. In: REGIONAL SEMINAR ON POST-HARVEST TECHNOLOGY FOR MAJOR CROPS, 2003, Kunming, China. Proceedings... China: Asian and Pacific Centre for Agricultural Engineering and Machinery (APCAEM); United Nations: ESCAP, 2003. p. 9-11.

NARESH, M. Pesquisa de Marketing: uma Orientação Aplicada. 4. ed. Porto Alegre: Bookman, 2004. cap. 6, p. 195.

REDMOND, E. C.; GRIFFITH, C. J. A Comparison and Evaluation of Research Methods Used in Consumer Food Safety Studies. International Journal of Consumer Studies, Oxford, v. 27, n. 1, p. 17-33, 2003. http://dx.doi.org/10.1046/j.14706431.2003.00283.x

TUOMINEN, P. Developing Risk-Based Food Safety Management. Helsinki: University of Helsinki, 2009. 132 p.

WOOD, M. J.; KERR, J. C. Basic Steps in Planning Nursing Research: from Question to Proposal. 6th. ed. Sudbury: Jones and Bartlett, 2006.

WORLD HEALTH ORGANIZATION - WHO. Food Safety and Foodborne Diseases. Geneva, 2007. (Fact Sheet, 237). Disponível em: <http://www.who.int/mediacentre/factsheets/ fs237/en>. Acesso em: 1 jun. 2011.

WORLD HEALTH ORGANIZATION - WHO. Sixty-Third World Health Assembly. WHA63.3. Geneva, 2010. 